the upper end of Pliocene estimates ${ }^{8}$, so one might anticipate them to simulate higher temperatures than those found in the reconstructions of the mean mid-Pliocene temperatures.

We feel that from a dynamical perspective, the most interesting feature of Pliocene warm climates is the weak zonal (Fig. 1) and meridional temperature gradients in the tropics ${ }^{9}$. These weakened gradients are not captured by the PlioMIP simulations. However, the inability of climate models to simulate the extent and patterns of Pliocene warmth ${ }^{7}$, specifically within the sub-tropics and equatorial upwelling regions, is a problem unresolved by a global seawater chemistry correction
(Fig. 1), or by a higher Earth-system sensitivity ${ }^{8}$ to $\mathrm{CO}_{2}$ forcing, as suggested in an accompanying News and Views ${ }^{10}$. Solving the problem will require the identification of mechanisms that can support weak temperature gradients ${ }^{1,9}$, possibly through better constraints on climate feedbacks in climate models ${ }^{1}$.

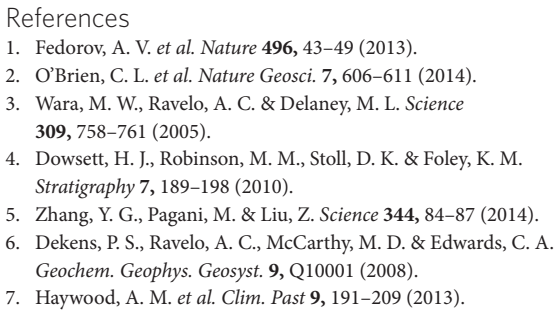

8. Pagani, M., Liu, Z., LaRiviere, J. \& Ravelo, A. C. Nature Geosci. 3, 27-30 (2009).

9. Brierley, C. et al. Science 323, 1714-1718 (2009).

10. Pagani, M. Nature Geosci. 7, 555-556 (2014).

Chris Brierley ${ }^{1 \star}$, Natalie Burls ${ }^{2}$, Christina Ravelo ${ }^{3}$ and Alexey Fedorov ${ }^{4}$

$\square \quad$ 'Department of Geography, University College London, London WC1E 6BT, UK. ${ }^{2}$ Department of Atmospheric, Oceanic \& Earth Sciences, George Mason University, Fairfax, Virginia 22030, USA. ${ }^{3}$ Department of Ocean Sciences, University of California, Santa Cruz, California 95064, USA. ${ }^{4}$ Department of Geology and Geophysics, Yale University, New Haven, Connecticut 06511, USA. *e-mail: c.brierley@ucl.ac.uk

\title{
Reply to 'Pliocene warmth and gradients'
}

\section{O'Brien et al. reply - Brierley et al. ${ }^{1}$} question our findings of elevated temperatures in the tropical warm pools during the Pliocene ${ }^{2}$. Focusing specifically on the mid-Pliocene warm period (about 3.3 to 3 million years ago), as framed by Brierley et al., we continue to find evidence for warmer than Holocene temperatures in the western Pacific warm pool in good agreement with PlioMIP simulations, especially in light of new $p_{\mathrm{CO}_{2}}$ reconstructions ${ }^{3}$.

First, seawater $\mathrm{Mg} / \mathrm{Ca}$ values were almost certainly lower than modern during the Pliocene (for example, ref. 4), although the exact magnitude and implications for the $\mathrm{Mg} / \mathrm{Ca}$ ratio of foraminiferal calcite remain uncertain ${ }^{5}$. Nevertheless, if the western Pacific warm pool was the same temperature as pre-industrial times, as Brierley et al. contest, we would expect the $\mathrm{Mg} / \mathrm{Ca}$ values of the foraminifera to be lower than those of the Holocene. Therefore, the observation of similar Holocene and midPliocene $\mathrm{Mg} / \mathrm{Ca}$ values indicates that sea surface temperatures were warmer than during the pre-industrial Holocene in the western Pacific warm pool, regardless of the correction used.

Second, Brierley et al. suggest that because sea surface temperature (SST) estimates based on uncorrected $\mathrm{Mg} / \mathrm{Ca}$ and the alkenone $\mathrm{U}_{37}^{\mathrm{k}}$ proxy agree at site ODP 847 in the east tropical Pacific, the $\mathrm{Mg} / \mathrm{Ca}$ seawater correction may be sitespecific, and therefore unnecessary at site ODP 806 in the heart of the warm pool. However, they provide no mechanistic rationale for this. Moreover, as we discussed in the Supplementary Information of our
Article, five out of six low-latitude sites for which $\mathrm{Mg} / \mathrm{Ca}$ and $\mathrm{U}_{37}^{\mathrm{k}}$ palaeotemperature estimates exist show better agreement when the seawater $\mathrm{Mg} / \mathrm{Ca}$ correction is applied. We also argue that faunal-based temperatures that appear to confirm little warming are biased by the upper limit of the modern calibration dataset, which is about $30{ }^{\circ} \mathrm{C}$ (ref. 6).

Third, we can also rule out a simple expansion of the western Pacific warm pool based on $\mathrm{TEX}_{86}^{\mathrm{H}}$ and $\mathrm{Mg} / \mathrm{Ca}$ temperature reconstructions from the South China Sea (ODP 1143) and Mg/Ca temperature estimates from the warm pool centre (ODP 806). Specifically, the Holocene $\mathrm{Mg} / \mathrm{Ca}$ temperature difference between the sites $^{7}$ persists throughout our 5-millionyear records ${ }^{2,8}$, implying that both the western Pacific and South China Sea were 1 to $2{ }^{\circ} \mathrm{C}$ warmer than Holocene during the Mid-Pliocene.

Fourth, a comparison between Plio-Pleistocene $\mathrm{TEX}_{86}^{\mathrm{H}}$; $\mathrm{U}_{37}^{\mathrm{k}}$ and $\mathrm{Mg} / \mathrm{Ca}$ temperature estimates (with an $\mathrm{Mg} / \mathrm{Ca}$ correction applied) and corresponding Holocene core-tops also indicates that the western Pacific warm pool, South China Sea and western Atlantic warm pool were warmer than Holocene estimates (Supplementary Fig. 1). Similarly, applying a regional, Bayesian-based $\mathrm{TEX}_{86}$ calibration $^{9}$ yields Pliocene SSTs that are $\sim 1-2{ }^{\circ} \mathrm{C}$ higher than modern, measured SSTs for both ODP 806 and ODP 1143. We also point out that for all of these proxy approaches, the Pliocene data points represent an average of several thousand years, and thus do not necessarily represent maximum Pliocene warmth.
Finally, the long-term trends in the $\mathrm{TEX}_{86}^{\mathrm{H}}$ data from the heart of the western Pacific warm pool ${ }^{10}$ and southern South China $\mathrm{Sea}^{2,10}$ clearly demonstrate that the warm pool temperatures have cooled from the Late Miocene to the Pleistocene (Supplementary Fig. 1a,b). In summary, the data we presented in ref. 2 and provide here strongly suggest that the warm pools of the Atlantic and Pacific were warmer than the Holocene during the Mid-Pliocene warm period and Pliocene as a whole.

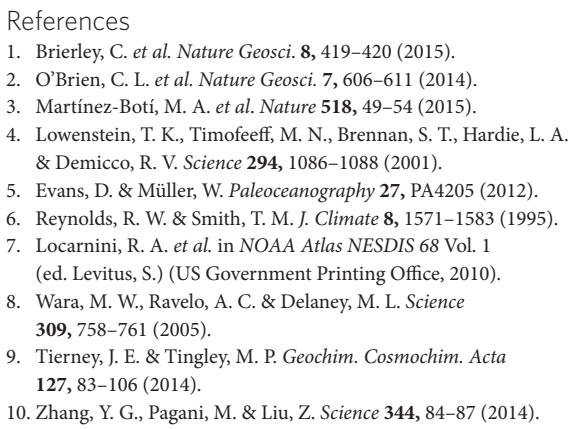

9. Tierney, J. E. \& Tingley, M. P. Geochim. Cosmochim. Acta 127, 83-106 (2014)

10. Zhang, Y. G., Pagani, M. \& Liu, Z. Science 344, 84-87 (2014).

Charlotte L. O'Brien ${ }^{1,2,3 *}$, Gavin L. Foster ${ }^{4}$, James W. B. Rae ${ }^{5}$ and Richard D. Pancost ${ }^{1,2}$ 'Organic Geochemistry Unit, School of Chemistry, University of Bristol, Bristol BS8 1TS, UK. ${ }^{2}$ Cabot Institute, University of Bristol, Bristol BS8 1UJ, UK. ${ }^{3}$ Department of Earth Sciences, University of Oxford, Oxford OX13AN, UK. ${ }^{4}$ Ocean and Earth Science, National Oceanography Centre Southampton, University of Southampton, Southampton SO14 3ZH, UK. ${ }^{5}$ Department of Earth and Environmental Sciences, Irvine Building, University of St Andrews, St Andrews KY16 9AL, UK. *e-mail: charlotte.obrien@earth.ox.ac.uk 